\title{
CONCRETE IN THE MARINE ENVIRONMENT - A REVIEW WITH EMPHASIS ON TROPICAL COASTAL APPLICATIONS
}

\author{
W.P.S. DIAS, \\ Department of Civil Engineering, University of Moratuwa, Moratuwa.
}

\author{
(Date of receipt : 25 September 1992) \\ (Date of acceptance : 12 February 1993)
}

\begin{abstract}
The effect of the marine environment on concrete depends on the climate and the zone of exposure. Degradation of concrete takes place due to a self reinforcing permeation - chemical attack - cracking - permeation cycle. Chemical attack can take place in the concrete or in the steel, if the concrete is reinforced. Cracking can occur due to loading as well as physical and chemical phenomena, either internal or external. Permeation of both water and various harmful ions will depend on the quality of the concrete. This paper reviews field and laboratory investigations on the effects of a variety of environments on various types of concretes. It concludes with a review of specifications for concrete mix design, including water/cement ratio, cenient type and content, admixture type and aggregate grading specifications for designing concrete mixes to withstand the marine environment.
\end{abstract}

Key words: Chloride ingress, Concrete, Marine environment, Mix design, Permeability, Pozzolan, Sulphate attack, Tricalcium aluminate.

\section{THE MARINE ENVIRONMENT AND CONCRETE}

\section{Zones of Exposure}

The marine environment, because of physical and chemical factors, is perhaps the most severe environment that concrete has been called upon to withstand. Figure 1 gives factors (with examples of each) that have to be taken into account when assessing the performance of concrete in a marine environment. The impact of the marine environment on concrete will vary qualitatively depending on the zone involved. Mehta ${ }^{1}$ has classified the marine environment into three zones, namely atmospheric, tidal and submerged, while Fookes $e t$ al ${ }^{2}$ have used a slightly different terminology, introducing a fourth zone called the splash zone between the atmospheric and tidal zones. Concrete in the tidal and submerged zones is more susceptible to chemical deterioration. However, if the concrete is reinforced, corrosion would be more likely to take place in the atmospheric and tidal zones than in the submerged zone, even though carbonation would be less in the former zones. Where physical deterioration is concerned, concrete is most susceptible in the tidal zone. In addition to freeze-thaw problems in cold climates, the tidal zone will 
experience wetting and drying, with consequent salt crystallization stresses, in hot climates.

\section{Climatological Considerations}

Apart from the zones of exposure, differing climates will have different effects on concrete. A comprehensive table of the occurrence of reinforced concrete deterioration for four different marine climates is given by Fookes $e$ t al. ${ }^{2}$. The above authors also indicate some environmentally related stresses that can be experienced by concrete structures in marine environments, as follows ${ }^{2}$ :

$\begin{array}{lll}\text { Expansion of water due to freezing } & 200 & \mathrm{MPa} \\ \text { Crystallization of salts } & 2-20 \mathrm{MPa} \\ \text { Hydration of salts } & 100 \mathrm{MPa} \\ \text { Expansion of clay } & 2 & \mathrm{MPa} \\ \text { Wave impact in existing cracks } & 100 \mathrm{MPa} \\ \text { Thermal movement in restrained concrete } & 0.5 \mathrm{MPa} / \mathrm{C} .\end{array}$

\section{Unreinforced concrete for coastal applications in the tropics}

Apart from being an economical building material, concrete is especially suited for tropical marine environments, where the warmer temperatures may promote corrosion in steel structures and marine borer activity in wooden ones. ${ }^{3}$ As freezing and thawing is not present in the tropics, the principal causes of physical deterioration are the wetting and drying cycles and salt crystallization in the evaporation zone. Wick action in the concrete may cause the area affected to be above the actual area of contact with sca watcr. Shrinkage, which is very high in dry tropical climates, may also result in crack initiation and growth.

Where prestressed or reinforced concrete is concerned, the primary concern regarding the hardened concrete is permeability to chloride ions, for corrosion protection. Unreinforced concrete may not require the same concern regarding permeability, especially because sulphate attack is not very pronounced in sea water. Nevertheless, it is prudent to use low water/cement ratios in concrete production, as this ensures not only good durability, but also high strength and abrasion resistance, that is required for unreinforced concrete to withstand the continuous impact of waves on coastal structures. 


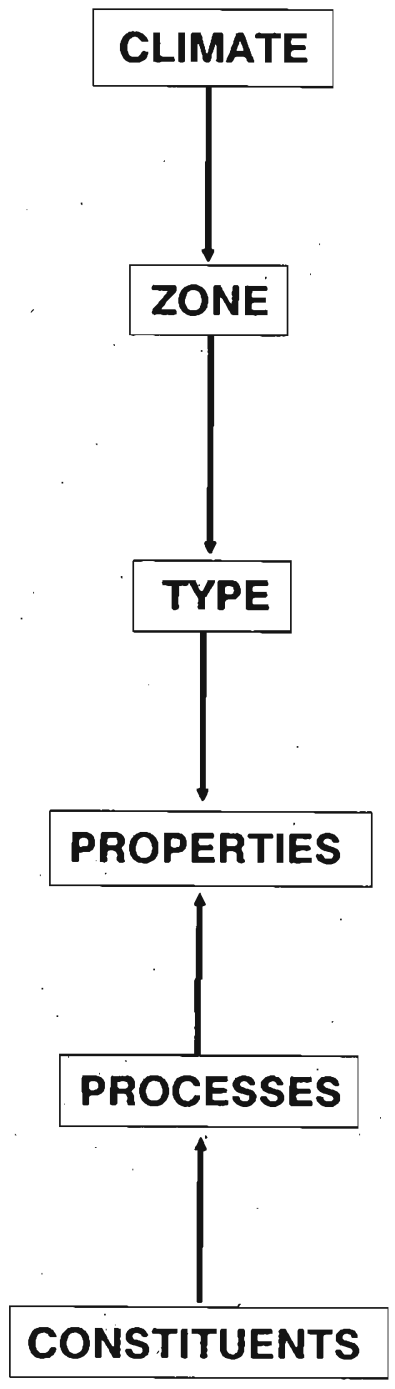

Cold

Temperate

Hot Dry

Hot Wet

Atmospheric

Splash

Tidal

Submerged

Deep-Sea

Prestressed

Reinforced

Fibre reinforced

Unreinforced

Strength

Durability

Permeability

Compaction

Cover

Curing

Transporting

Water/Cement Ratio

Cement or Binder Type \& Content

Aggregate grading

Reinforcement

Figure 1: Factors influencing the properties of concrete in the marine environment. 


\section{CHEMICAL ATTACK}

\section{Chemical composition of concrete and sea water}

Hydrated pastes of portland cement contain the following major components ${ }^{1}$ :

(i) a microcrystalline calcium silicate having an approximate chemical composition $3 \mathrm{CaO} .2 \mathrm{SiO}_{2} .3 \mathrm{H}_{2} \mathrm{O}$.

(ii) crystalline calcium hydroxide $\mathrm{Ca}(\mathrm{OH})_{2}$, which may be $24 \%$ by weight in completely hydrated pure portland cement pastes. This percentage will be lower in blended cements and blastfurnace slag cements.

(iii) the crystalline monosulphate hydrate, $3 \mathrm{CaO} \cdot \mathrm{Al}_{2} \mathrm{O}_{3} \cdot \mathrm{CaSO}_{4} \cdot 18 \mathrm{H}_{2} \mathrm{O}$. This hydrate is not present in sulphate resisting cements which contain a minimal amount of tricalcium aluminate, denoted hereafter as $\mathrm{C}_{3} \mathrm{~A}$ according to cement chemistry conventions.

On the other hand the composition of sea water in grams per litre is as follows ${ }^{1}$ :
(i) $\mathrm{NaCl}$
$27.0 \mathrm{~g} / \mathrm{l}$
(ii) $\mathrm{MgCl}_{2}$
$3.2 \mathrm{~g} / \mathrm{l}$
(iii) $\mathrm{MgSO}_{4}$
$2.2 \mathrm{~g} / \mathrm{l}$
(iv) $\mathrm{CaSO}_{4}$
$1.3 \mathrm{~g} / \mathrm{l}$

The $\mathrm{CO}_{2}$ concentration in the sea is the highest of all gases, varying between 35 to $60 \mathrm{ml} / \mathrm{l}$, the $\mathrm{CO}_{2}$ being both dissolved physically and combined chemically in the water ${ }^{3}$. Dissolved oxygen ranges from 5 to $10 \mathrm{ml} / 1$ and will affect corrosion as well as biological activity. ${ }^{3}$

The $\mathrm{pH}$ of sea water is typically around 8 , making it slightly alkaline. Although dissolved carbon dioxide may lower the $\mathrm{pH}$ to $7^{1}$, in general the buffering mechanism of the carbon dioxide-carbonate system maintains the $\mathrm{pH}$ at around $8^{3}$ - i.e. when $\mathrm{CO}_{2}$ is dissolved in sea water, although the $\mathrm{pH}$ is reduced by the formation of carbonic acid $\left(\mathrm{H}_{2} \mathrm{CO}_{3}\right)$, and this reacts with $\mathrm{CaCO}_{3}$ to form $\mathrm{HCO}_{3}$ - ions, which tends to increase the $\mathrm{pH}$ once again.

\section{Chemistry of reactions between concrete and sea water}

The effect of dissolved $\mathrm{CO}_{2}$ on concrete are as follows ${ }^{1}$ :

$$
\mathrm{CO}_{2}+\mathrm{Ca}(\mathrm{OH})_{2} \longrightarrow \underset{\text { (aragonite) }}{\mathrm{CaCO}_{3}}+\mathrm{H}_{2} \mathrm{O} \stackrel{\mathrm{CO}_{2}}{\longrightarrow} \mathrm{Ca}\left(\mathrm{HCO}_{3}\right)_{2}
$$




$$
\begin{aligned}
& \mathrm{CO}_{2}+\left[\mathrm{Ca}(\mathrm{OH})_{2}+3 \mathrm{CaO} \cdot \mathrm{Al}_{2} \mathrm{O}_{3} \cdot \mathrm{CaSO}_{4} \cdot 18 \mathrm{H}_{2} \mathrm{O}\right] \underset{3 \mathrm{CaO}_{2} \mathrm{Al}_{2} \mathrm{O}_{3} \cdot \mathrm{CaCO}_{3} \cdot \mathrm{XH}_{2} \mathrm{O}+\underset{(\text { (gypsum) }}{\longrightarrow}}{\mathrm{CaSO}_{4} \cdot 2 \mathrm{H}_{2} \mathrm{O}} \\
& 3 \mathrm{CO}_{2}+3 \mathrm{CaO} \cdot 2 \mathrm{SiO}_{2} \cdot 3 \mathrm{H}_{2} \mathrm{O} \longrightarrow \\
& \begin{array}{l}
\text { (aragōnite) } \\
\text { (araCO }
\end{array}
\end{aligned}
$$

Both calcium bicarbonate and gypsum are soluble in sea water, causing leaching of material and consequent weakening. The insoluble aragonite $\left(\mathrm{CaCO}_{3}\right)$ is deposited as a surface layer.

The effect of magnesium salts is shown below ${ }^{1}$ :

$$
\begin{aligned}
& \mathrm{MgCl}_{2}+\mathrm{Ca}(\mathrm{OH})_{2} \longrightarrow \underset{\text { (brucite) }}{\mathrm{Mg}(\mathrm{OH})_{2}}+\mathrm{CaCl}_{2}
\end{aligned}
$$

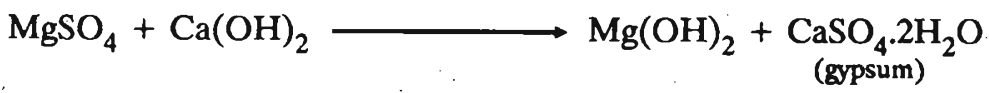

$$
\begin{aligned}
& \mathrm{MgSO}_{4}+\left[\mathrm{Ca}(\mathrm{OH})_{2}+3 \mathrm{CaO} \cdot \mathrm{Al}_{2} \mathrm{O}_{3} \cdot \mathrm{CaSO}_{4} \cdot 18 \mathrm{H}_{2} \mathrm{O}\right] \longrightarrow \\
& \mathrm{Mg}(\mathrm{OH})_{2}+3 \mathrm{CaO} \cdot \mathrm{Al}_{2} \mathrm{O}_{3} \cdot 3 \mathrm{CaSO}_{4} \cdot 32 \mathrm{H}_{2} \mathrm{O} \\
& \mathrm{MgSO}_{4}+\left[\mathrm{Ca}(\mathrm{OH})_{2}+3 \mathrm{CaO} \cdot 2 \mathrm{SiO}_{2} \cdot 3 \mathrm{H}_{2} \mathrm{O}\right] \\
& 4 \mathrm{MgO} \cdot \mathrm{SiO}_{2} \cdot 8 \mathrm{H}_{2} \mathrm{O}+\underset{(\text { gypsum) }}{\mathrm{CaSO}_{4} \cdot 2 \mathrm{H}_{2} \mathrm{O}}
\end{aligned}
$$

Calcium chloride and gypsum, being soluble in water, can cause weakening of the concrete, while the last conversion above is thought to be associated with brittleness and strength loss. The formation of ettringite is accompanied by disruptive expansion.

The chlorides in sea water can react with $\mathrm{C}_{3} \mathrm{~A}$ in the cement to form the chloroaluminate $\mathrm{C}_{3} \mathrm{~A} \cdot \mathrm{CaCl}_{2} \cdot 11 \mathrm{H}_{2} \mathrm{O}$. This may occur only when the $\mathrm{C}_{3} \mathrm{~A}$ content is greater than $8 \%$, as lower percentage of $\mathrm{C}_{3} \mathrm{~A}$ may be consumed by the gypsum that is present in normal cement. ${ }^{1}$ Although the formation of chloroaluminate is expansive, it may not be disruptive, but rather beneficial, because it fills up empty pore space, 4,5 and also has the effect of chloride binding, delaying the ingress of chloride ions to the zone of reinforcement. ${ }^{1}$ However, such chloride binding is not stable in sulphate environments (see section on Progress of Chemical attack).

\section{Calcium hydroxide}

It is the $\mathrm{Ca}(\mathrm{OH})_{2}$ component in hydrated portland cement that makes it most vulnerable to sea water attack. Not only can it be leached away as calcium bicarbonate and gypsum, causing material weakening, but such leaching. also makes the concrete 
more permeable, leading to the attack of other phases. Hence, the use of blended cements or the addition of partial cement replacement agents, which result in a lower amount of $\mathrm{Ca}(\mathrm{OH})_{2}$ upon hydration, will improve the marine durability of concrete. This has been confirmed by Gjorv, ${ }^{6}$ who established that concretes made with calcium aluminate cement, supersulphated cement and blastfurnace slag cements resisted the action of sea water fairly well, and by Smolczyk, ${ }^{7}$ whose field and laboratory work revealed that blastfurnace slag cements were more resistant to sea water and sea water salts respectively. The beneficial effect of using pozzolanic partial cement replacement agents such as trass ${ }^{6}$ and santorin earth ${ }^{8}$. has also been reported. Gjorv ${ }^{9}$ reports that the addition of $30 \%$ silica fume as a partial cement replacement reduced the $\mathrm{pH}$ from over 13 to 12. While this latter figure is not low enough to depassivate the steel (see section on the chemistry of corrosion), the reduction of alkalinity is beneficial for minimizing the risk of alkali-silica reaction. Gjorv also reports that the addition of silica fume increased electrical resistivity. but reduced chloride binding. ${ }^{9}$

\section{The level of tricalcium aluminate}

The $\mathrm{C}_{3} \mathrm{~A}$ level in the cement will determine the extent of ettringite formation, which is associated with disruptive expansion. However, the presence of chlorides in sea water is known to inhibit this expansive effect, perhaps as a result of chloroaluminate formation, ${ }^{8}$ and also because ettringite is more soluble in solutions containing chlorides as opposed to pure sulphate solutions. ${ }^{1}$

Although it has been suggested that the cubic crystalline form of $\mathrm{C}_{3} \mathrm{~A}$ will make portland cement more vulnerable to sulphate attack than the orthorhombic or tetragonal forms, there is a lack of consensus in this regard. ${ }^{1}$ On the other hand, it has been reported that more $4 \mathrm{MgO} . \mathrm{SiO}_{2} .8 \mathrm{H}_{2} \mathrm{O}$ is formed when the crystalline form of $\mathrm{C}_{3} \mathrm{~A}$ is orthorhombic or tetragonal instead of cubic..

Conjeaud $^{4}$ has reported that the morphology of ettringite associated with strength loss in cement mortars exposed to sea water is different to that found in water cured samples. She calls the former "Si-ettringite" as it contains up to about $5 \% \mathrm{SiO}_{2}$ with $0.2 \% \mathrm{Cl}$ and is not strictly stoichiometric.

In general, however, the level of $\mathrm{C}_{3} \mathrm{~A}$ in the cement does not seem to have much hearing on the performance of concrete in sea water. Gjorv ${ }^{6}$ found that even low $C_{3} A$ cement contents were affected by sea water when using the rather high water/cement ratios between 0.55 and 0.65 . On the other hand, $C_{3} A$ levels of $12-17 \%$ have given excellent long term durability when low water/cement ratios have been used. ${ }^{1}$ 
The chemistry of corrosion

In a high $(\mathrm{OH})^{-}$concentration, the anodic reaction will be as follows ${ }^{1}$ :

$$
\mathrm{Fe}+3(\mathrm{OH})^{-} \longrightarrow 1 / 2 \mathrm{Fe}_{2} \mathrm{O}_{3} \cdot 3 \mathrm{H}_{2} \mathrm{O}+3 \mathrm{e}^{-}
$$

The ferric oxide is insoluble in an alkaline medium and will act as a protective layer on the steel.

In high $\mathrm{Cl}^{-}$concentration, where oxygen is present, the anodic and cathodic reactions will be as follows ${ }^{1}$ :

Anodic : $\mathrm{Fe}+2 \mathrm{Cl}^{-}$

$\mathrm{FeCl}_{2}$ $\mathrm{Fe}^{2+}+2 \mathrm{Cl}^{-}+2 \mathrm{e}^{-}$

Cathodic: $1 / 2 \mathrm{O}_{2}+\mathrm{H}_{2} \mathrm{O}+2 \mathrm{e}^{-}$ $2(\mathrm{OH})^{-}$

Since the concentration of dissolved oxygen is less than $10 \mathrm{ml} / \mathrm{l}$ in sea water, while being around $210 \mathrm{ml} / \mathrm{l}$ in air, it is the atmospheric and tidal zones that are susceptible to corrosion, as opposed to the submerged zone. ${ }^{1}$

Because the presence of $\mathrm{Cl}^{-}$and $(\mathrm{OH})^{-}$ions have opposing effects on the onset of corrosion, it is convenient to define a minimum $\mathrm{Cl}^{-} /(\mathrm{OH})^{-}$ratio required to initiate corrosion; this ratio is generally accepted as $0.63 .^{1}$ It is suggested by some that a higher ratio may be tolerated because the $\mathrm{C}_{3} \mathrm{~A}$ in cement can remove some of the $\mathrm{Cl}^{-}$ in the form of the chloroaluminate; this however, may afford only temporary relief. ${ }^{1}$

In this context, the $\mathrm{pH}$ of the cement is the controlling factor governing the onset of corrosion. While the $\mathrm{pH}$ of hydrated cement paste is between 13 and 14 , significant corrosion will take place only if the $\mathrm{pH}$ is reduced below $11.5^{1}$ The $\mathrm{pH}$ can be so reduced by carbonation in $\mathrm{CO}_{2}$ rich sea water or by $\mathrm{Mg}^{2+}$ ions which remove (OH)from the solution phase by the precipitation of the relatively insoluble $\mathrm{Mg}(\mathrm{OH})_{2}$.

\section{Progress of Chemical Attack}

The first phase of attack, on the surface zone itself, is the precipitation of aragonite and the leaching away of this aragonite as the bicarbonate. ${ }^{1}$ Aragonite formations have been reported after 7 days of exposure; these gradually form a continuous layer in about 3 months and can increase to around 300 microns thickness after 2 years. ${ }^{4}$

While Mehta ${ }^{1}$ reports that second phase attack from $\mathbf{M g}^{2+}$ ions cannot take place until $(\mathrm{OH})^{-}$depletion has taken place, Buenfeld and Newman ${ }^{5}$ report the formation of brucite, i.e. $\mathrm{Mg}(\mathrm{OH})_{2}$, after only 24 hours of exposing concrete and mortar specimens to sea water. The aragonite layer forms over this layer of brucite, which can be 
typically 20-50 microns thick. ${ }^{4}$ In the third phase, $\left(\mathrm{SO}_{4}\right)^{2-}$ ions are removed from sea water by the formation of ettringite and gypsum. Although $\mathrm{C}_{3} \mathrm{~A}$, if present in hydrated cement paste, can convert $\mathrm{Cl}^{-}$into chloroaluminate, this compound is not stable in a sulphate environment and converts to ettringite, releasing the $\mathrm{Cl}^{-1}$. The final phase of attack is the onset of corrosion due to the high $\mathrm{Cl}^{-}$concentration in the reinforcement zone. The progress of chemical attack is to a large extent dependent on the permeability of the concrete, and this aspect will be considered in the section on permeability, which will also deal with permeability reducing phenomena.

\section{Biological effects}

Marine borers are known to attack timber and weak concrete in marine structures. These borers, which depend on the chemical dissolution of calcium carbonate and a mechanism of rasping and wearing or chewing and ingestion, are more likely to be found in warmer climates, in sea water at a $\mathrm{pH}$ of 7.5 to $8.5^{3}$ The accumulation of organisms on structures can increase their weight and the drag forces imposed on them. Such fouling is of particular concern in offshore structures. The specific gravity of the fouling ranges from 1.0 for soft fouling to 1.3-1.4 for hard fouling. ${ }^{3}$

\section{PERMEABILITY}

\section{Factors that affect watertightness}

The watertightness of a concrete structure can be affected by the following factors ${ }^{1}$ :

(i) Cracks in concrete - arising out of transport stresses, deflection due to load, thermal stresses, corrosion of reinforcement, freeze-thaw or wetting and drying cycles, and expansive products of chemical reactions.

(ii) Poor concreting practice - including inadequate compaction, improper placement (e.g. segregation or thick layers of laitence) and poorly formed joints.

(iii) Permeability of the concrete - although poorly graded aggregate may also contribute to this, it is determined mainly by the permeability of the cement paste matrix.

The permeability of the paste is primarily dependent on the water/cement ratio of the mix, a high ratio leading to a greater capillary pore space and causing a permeable paste. The permeability of concrete increases rapidly as the water/cement ratio is increased beyond $0.6 .^{10}$ Hence, in order to ensure low permeability, a maximum free water/cement ratio should be specified. Specifications range from 0.4 to 0.5 for concrete in the splash zone, ${ }^{11}$ although it would be prudent to adhere to the lower limit. It must be appreciated however, that there will be variations in the localized 
water/cement ratio within the concrete, due to bleeding ${ }^{12}$ and other factors. A paste of nominal water/cement ratio of 0.45 may have local variations ranging from 0.2 to $1.0 .^{13}$

An increase in aggregate size will result in greater areas of high localized water/cement ratios, since aggregates trap the bleed water, causing increases in permeability and micro-cracking. ${ }^{12}$ On the other hand, a larger aggregate size will enable lower water/cement ratios to be used because of the reduced water demand for workability. However, in rich mixes, such as those used for marine concretes, the former effect will predominate. ${ }^{10}$ The presence of mix particles that are finer than cement particles will inhibit bleeding and also contribute to greater homogeneity. ${ }^{12}$ The use of silica fume as a partial cement replacement agent is particularly relevant in this context, as these particles are 50 to 100 times smaller than cement particles. ${ }^{14}$

Sometimes a minimum cement content is specified as well, because this is easier to control than the water/cement ratio. Here again, specifications range from 360 to $400 \mathrm{~kg} / \mathrm{m}^{3}$ for concrete in the splash zone, ${ }^{11}$ and in such cases it would be prudent to adhere to the upper limit.

Another way of reducing the permeability of the paste matrix is to reduce the amount of end-product $\mathrm{Ca}(\mathrm{OH})_{2}$, which is susceptible to being leached away. Reduction in paste porosity has been obtained by the use of rice husk ash ${ }^{1}$ and santorin earth ${ }^{8}$ as partial cement replacement pozzolans. Mehta ${ }^{1}$ points out, however, that the reactivity of the pozzolan is an important consideration, as slow reacting ones like pulverized fuel ash ( $\mathrm{pfa}$ ) may take around three months to cause a decrease in porosity. One of the fastest reacting pozzolans currently available is silica fume. ${ }^{14}$ The conversion of the crystalline $\mathrm{Ca}(\mathrm{OH})_{2}$ to the poorly crystalline calcium silicate hydrates by the above pozzolans will make the paste structure more uniform and also reduce the potential for micro-cracking, since the interfaces between the crystalline $\mathrm{Ca}(\mathrm{OH})_{2}$ and the poorly crystalline hydrates in hydrated cement paste are considered to be points of crack initiation. ${ }^{12}$ Permeability is related to the degree of interconnection of capillary pores and microcracks. ${ }^{12}$ Hence the reduction of permeability should be attempted by measures that reduce both the capillary porosity and the potential for micro-cracking.

\section{Ingress of ions}

Conjeaud ${ }^{4}$ found that the penetration of $\mathrm{Cl}^{-}$was much greater than that of $\mathrm{SO}_{4}^{2-}$ into mortar bar specimens. Gjorv and Vennesland ${ }^{15}$ found that $\mathrm{Cl}^{-}$can penetrate to a depth of $30 \mathrm{~mm}$ in two years even in a mortar specimen with a water/cement ratio as low as $\mathbf{0 . 4}$. Hence, they conclude that it is only a matter of time until $\mathrm{Cl}^{-}$reaches the reinforcement zone even through good quality concrete. The same investigators also found that the paste water/cement ratio (varied from 0.4 to 0.6 ) had a significant effect 
on $\mathrm{Cl}^{-}$penetration in the first $10 \mathrm{~mm}$ from the surface but no effect beyond $20 \mathrm{~mm}$ from the surface. ${ }^{15}$

In the latter region, the cement composition seemed to have an effect on $\mathrm{Cl}^{-}$ penetration, pure OPC pastes being more susceptible than blended cements. ${ }^{15}$ They infer from this that ion exchange is important for $\mathrm{Cl}^{-}$penetration in this zone, as pure OPC pastes have more $(\mathrm{OH})^{-}$than blended cement pastes. They also found that an OPC paste with as much as $8.6 \% \mathrm{C}_{3} \mathrm{~A}$ did not slow down the $\mathrm{Cl}^{-}$penetration by chloride binding. This is explained by suggesting that either greater percentages of $\mathrm{C}_{3} \mathrm{~A}$ are required or that chloride binding is more a physical adsorption process than a chemical reaction.

\section{Permeability reducing phenomena}

Buenfeld and Newman ${ }^{5,16}$ found that the electrical resistance of concrete and mortar exposed to sea water increased gradually. They attribute this to a loss of permeability due to both surface and bulk effects. This was deduced from their observations that the resistance dropped significantly, but not to the original value, when a $1 \mathrm{~mm}$ layer was ground off the surface after 18 weeks' exposure. ${ }^{16}$

The surface effect is caused by the formation of brucite and aragonite layers. These layers were observed using the scanning electron microscope by the above researchers as well as by Conjeaud, ${ }^{4}$ who reported that they slowed down $\mathrm{Cl}^{-}$and $\left(\mathrm{SO}_{4}\right)^{2-}$ diffusion inta mortar specimens; the latter also found a deceleration in the rates of calcium chloroaluminate and ettringite formation, calcium hydroxide consumption and compressive strength loss. The brucite layer has been detected after only 24 hours of exposure ${ }^{5}$ and its thickness quoted as being typically 20-50 microns. ${ }^{4}$ Conjeaud $^{4}$ says that the thickness of this layer does not increase beyond two days, although its crystallization improves; Buenfeld and Newman, however, report an increase in thickness. 5

The aragonite layer has been detected after 4 days in some cases but only after 28 days in others. ${ }^{5}$ It has been found to form a continuous layer over the brucite deposit after 3 months ${ }^{4}$ and increase in thickness up to around 300 microns after exposure of 6 months ${ }^{5}$ to 2 years. ${ }^{4}$. There is, however, supposed to be great variability in this thickness. ${ }^{4,5}$ Conjeaud ${ }^{4}$ has tried to relate the development of these layers to exposure times of between 1 and 3 months, after which deceleration was obtained for various phenomena, as described beforehand.

Surface water absorption tests performed after pre-drying to $105^{\circ} \mathrm{C}$ showed that sea water exposed beams absorb less water than those cured in lime water; this was used to suggest that wetting and drying in the tidal zone may not have an adverse 
effect on the protective layers. ${ }^{16}$ However it is not clear whether alternate wetting and drying by sea water would be sufficient to produce these layers in the first place or whether a large number of such cycles would in fact lead to their deterioration.

Where this surface phenomenon is concerned, Buenfeld and Newman ${ }^{5}$ point out that it is very sensitive to the level of $\mathrm{Mg}^{2+}$ in sea water, not only for the formation of brucite, but also because $\mathrm{Mg}^{2+}$ stimulates the formation of aragonite in preference to calcite. Hence, they emphasize that sea water used in laboratory experiments be renewed regularly (e.g. every month) in order to prevent depletion of $\mathrm{Mg}^{2+}$, which is present only in concentrations of $1.2 \mathrm{~g} /$. This may explain why this surface phenomenon is not reported by some investigators.

The bulk reduction in permeability reported by Buenfeld and Newman is associated with the reduction in volume of larger pores. ${ }^{5}$ Mercury intrusion porosimetry was used to show that all mortars which showed a bulk increase in resistance had a smaller volume of pores greater than $100 \mathrm{~nm}$ and a larger volume of smaller pores. This effect was less in a zero $\mathrm{C}_{3} \mathrm{~A}$ mix, where the chloroaluminate would not have been formed. Hence, the formation of chloroaluminate which can expand into the pore space 4 is suggested as a cause for the decrease in bulk permeability. ${ }^{5}$ It should be noted that a pfa mix showed a bulk reduction in resistance, accompanied by an increase in the volume of pores greater than $100 \mathrm{~nm}$.

\section{New technologies for protection}

The use of polymers in concrete can improve watertightness. Polymers can be applied in 4 ways - i.e. polymer coatings, polymer impregnation, the use of polymer modified cement and the exclusive use of polymers as the binder. ${ }^{17}$ Because of the cost involved, polymer concrete may have applications primarily in repair work. However, both laboratory ${ }^{18}$ and full scale $^{19}$ exposure tests have confirmed the superior performance of the first two techniques over conventional concrete. Epoxy coated reinforcing bars are another option for protection, in this case, directly of the reinforcement. 20

\section{DEGRADATION}

\section{General}

In general, the degradation of concrete in the marine environment is associated with the presence of water, and with various expansion phenomena. ${ }^{21}$ Examples of these are the sulphate attack of concrete and the corrosion of reinforcement. Mehta ${ }^{12}$ has drawn attention to the importance of micro-cracking and crack growth in concrete for the progress of deterioration, as permeation of harmful ions via such cracks would be 
quicker than by diffusion through sound concrete. It should be noted that the permeation - chemical attack (of either concrete or steel) - cracking - permeation cycle (Figure 2) is a self-reinforcing one.

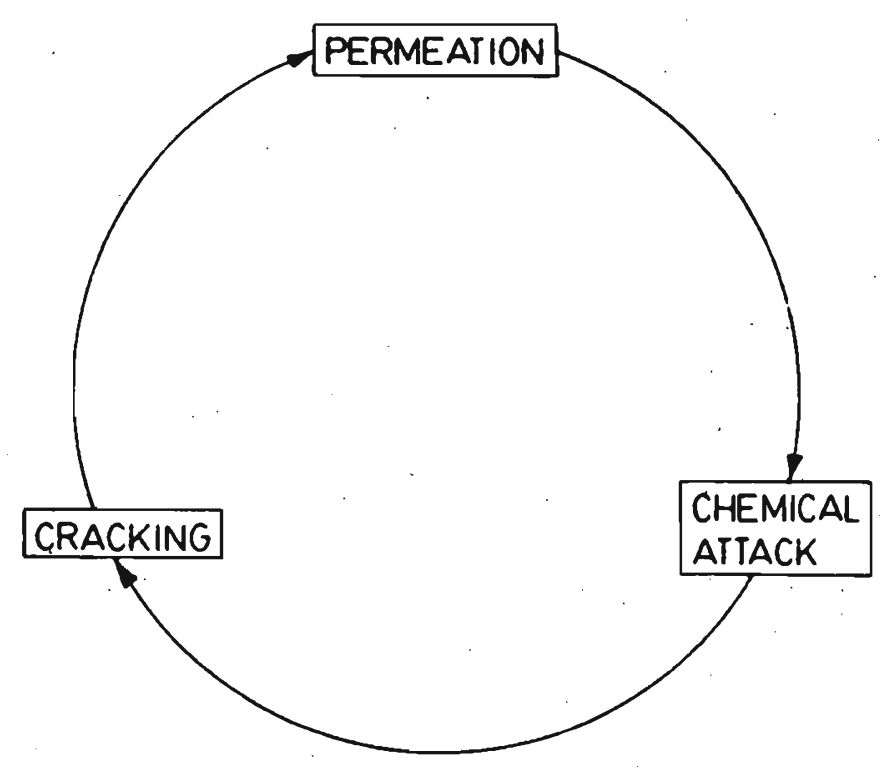

Figure 2: Cycle of degradation

Cracking or crack growth can occur as a result of internal chemical reactions as well, e.g. alkali-silica reaction, where the alkalis are found in the cement and the reactive silica in the aggregate. Here too, external moisture is probably required to initiate or promote the reaction. Another cause of cracking may be physical e.g. shrinkage, freeze-thaw cycles or salt crystallization. Salt crystallization is more relevant for tropical climates than is freeze-thaw degradation. The crystallization of salt in the evaporation zone causes expansive strains resulting in spalling, as in freeze-thaw damage. This similarity in mechanism is the reason that salt crystallization techniques are used for determining frost susceptibility of aggregates. ${ }^{21}$

\section{Field observations}

When the cement content in concrete has been greater than around $400 \mathrm{~kg} / \mathrm{m}^{3}$, concrete has performed well in marine environments up to 50 years and longer, even 
though the $C_{3} A$ contents of the cements were as high as $14-17 \%$; furthermore, cement contents as high as $600 \mathrm{~kg} / \mathrm{m}^{3}$ were not found to be detrimental in mortar cubes. ${ }^{1}$ On the other hand concrete with a low cement content (e.g. $220 \mathrm{~kg} / \mathrm{m}^{3}$ ) had to be repaired after 20 years' service. ${ }^{1}$ In general, cements which contained pozzolan and slag have resulted in concretes that are more durable in coastal and marine works. ${ }^{1,7}$ Poor concreting practice and cracks induced in concrete have also shortened the life of concrete structures exposed to marine conditions. ${ }^{1}$ Concrete that has deteriorated due to sea water attack shows loss of material, especially at edges, and is soft and weak; it may also be cracked severely. ${ }^{1,7}$ Concrete cubes stored in the spray (i.e. atmospheric and splash), tidal and submerged zones under U.K. exposure conditions indicated that strength development was best in the spray zone, while susceptibility to freeze-thaw cycles was greatest in the tidal zone; carbonation in the splash zone was also found to be minimal, because of the wet, humid conditions. ${ }^{22}$ Salt crystallization has been found to be essentially a surface phenomenon, producing flaking and spalling in successive layers, without an overall swelling effect, sometimes resulting in patchy erosion and at other times producing Liesegang ring "onion skin" spalling. 21

\section{Laboratory immersion tests}

Some of the properties that have been measured after immersing concrete in sea water are compressive strength, $4,6,8,23$ flexural strength, ${ }^{6}$ dynamic modulus of elasticity ${ }^{23}$ and length change. ${ }^{23}$ Where strength is concerned, it initially increases, since hydration continues to take place. Hence, initially any strength loss is relative - i.e. with respect to the strength of water cured specimens - and may be expressed as the ratio of the former to the latter. ${ }^{4}$ It may take 6 months or longer, depending on the concrete type, for absolute strength properties to show a declining trend. ${ }^{6,23}$ Gjorv $^{6}$ found that flexural strength started decreasing after around 5-10 years whereas compressive strength remained unaffected for 30 years.

Lower water/cement.ratios were seen to have a significant effect on the resistance to sea water, i.e. ratios of 0.4 compared to $0.6^{23}$ and 0.55 compared to $0.65^{6}$

Blended cements such as blastfurnace slag cements were found to produce concrete with better sea water resistance, ${ }^{6,23}$. while the addition of pozzolans such as trass $^{6}$ and santorin earth ${ }^{8}$ generally produced marked improvements. Gjorv ${ }^{6}$ found that high $\mathrm{C}_{3} \mathrm{~A}$ cement concrete performed badly, although it should be noted that his lowest water/cement ratio was 0.5 and highest cement content $417 \mathrm{~kg} / \mathrm{m}^{3}$. Although Gjorv $^{6}$ did not find any difference in durability between concretes where fresh water and sea water had been used as mixing water, Nishibayashi $e t$ al. ${ }^{23}$ found that using sea water as mixing water affected the durability of OPC concrete, especially at the higher water/cement ratio of 0.6. Nishibayashi et al. also found that precuring (i.e. immersion in sea water after 28 days of presumably air or moist curing) had no beneficial effect 
and in some cases a detrimental effect, again in OPC concrete having the higher water/cement ratio of 0.6 and where sea water had been used for mixing. ${ }^{23}$ They attribute this to the possibility that the ettringite formation in concretes exposed directly (i.e. after 3 days) to sea water is less disruptive than in precured concretes, because the degree of cement hydration in the former is less, thus causing less restraint to the ettringite expansion. Although there may be some evidence in support of this deduction in Gjorv's results - whose precuring, however, was for 6 weeks in fresh water and 6 weeks in air - some of his concretes did actually show improved durability after precuring. ${ }^{6}$

It should be noted that no connection has been highlighted between permeability reducing phenomena and compressive strength changes, except by Conjeaud. ${ }^{4}$

\section{Laboratory accelerated tests}

Some investigators have used alternate wetting and drying tests ${ }^{23,24}$ as accelerated methods of investigating the effect of sea water on concrete. Their methods consist of repeated cycles of immersion followed by oven drying to temperatures between 50 and $80^{\circ} \mathrm{C}$. The upper temperature may be a little too high, as thermal shock could be introduced. ${ }^{24}$ Each phase (i.e. wetting or drying ) was of the order of 6-24 h duration. Dynamic modulus of elasticity and length change have been used to monitor the degradation of concrete, in addition to compressive strength. The results of such investigations are broadly in keeping with the results of immersion testing, with respect to the effect of various parameters. For example, higher water/cement ratios and higher salt concentrations were found to result in greater deterioration, and blended cements such as blastfurnace slag cement produced concretes with better durability properties. ${ }^{23,24}$

Nishibayashi et al. ${ }^{23}$ have developed sea water resistance factors, in order to evaluate the performance of different concretes. These are based on the number of cycles required to reduce the dynamic modulus to $60 \%$ of its original value, and the length change after 200 cycles. Nishibayashi et al..$^{23}$ have also tried to correlate their accelerated test results with the long term immersion test results of Gjorv ${ }^{6}$, and conclude that one of their cycles $\left(24 \mathrm{~h}\right.$ wetting and $24 \mathrm{~h}$ drying at $60-80^{\circ} \mathrm{C}$ ) corresponds to about 50-60 days immersion in sea water.

It should be noted however, that where the concrete in the tidal zone is concerned, the wetting and drying tests may represent real time scale phenomena, as opposed to accelerated phenomena. This is especially so with regard to the question as to whether permeability reducing phenomena will be experienced in the tidal zone. ${ }^{5}$ 


\section{Freeze-thaw degradation}

Where freeze-thaw conditions are anticipated, air entrainment of the concrete is recommended. These discrete bubbles of air (of magnitude around $0.05 \mathrm{~mm}$ ) relieve the pressure caused by water expansion during freezing and also limit the growth of ice particles. ${ }^{10}$ For air entrainment to be effective, the spacing between the bubbles should not exceed $0.2 \mathrm{~mm}^{10}$, and the FIP recommendation is that $4-7 \%$ of air be entrained. 25

Laboratory investigations on freeze-thaw durability have yielded the following general conclusions $^{26}$ :

(i) Non air entrained concretes perform poorly, regardless of the water/cement ratio employed.

(ii) Air entrained concretes perform well, but the performance drops when the water/cement ratio exceeds 0.7 .

(iii) Even though the bubble spacing for superplasticized concretes is greater than 0.2 $\mathrm{mm}$, these concretes perform well.

(iv) Silica fume concretes incorporating high percentages of silica fume (10-20\% or more) perform poorly, even with over $4 \%$ air entrainment, due to unsatisfactory bubble spacing.

Freeze-thaw tests have been carried out at natural weathering sites as well. However, attempts to correlate results from such trials with-laboratory results have not been very successful ${ }^{26}$, due to significant differences in the nature of the exposure.

\section{Reinforcement corrosion}

Reinforcement corrosion is a very significant contributory factor towards degradation, not only because of the attack on the reinforcement, but also because the products of corrosion are around 2 to 4 times as bulky as the original steel, ${ }^{27}$ and hence cause cracking or spalling of concrete. In general, steel embedded in good quality concrete has been known to exhibit very little corrosion, even after 35 years of immersion in sea water. ${ }^{28}$ However, reinforced or prestressed concrete in the tidal and atmospheric zones is probably more susceptible to corrosion. The electrochemical corrosion of steel embedded in concrete depends on a number of factors, including chloride penetration, oxygen availability and the ratio of cathodic to anodic areas. ${ }^{27,28}$ Low quality (i.e. very porous) concrete will particularly enhance corrosion, because parts of the steel surface will be separated from the protective concrete by voids. ${ }^{28}$ Where cracked concrete is concerned, cracks parallel to the steel are of greater concern than 
those transverse to the steel; there is also some evidence of crack healing in sea water. $^{28}$

\section{Cyclic loading tests}

Apart from the material degradation that takes place as described above, both offshore and coastal structures will be subjected to cyclic stresses. Cyclic loading tests performed on beams have indicated that fatigue life is reduced in seawater compared to that in air, particularly at high water/cement ratios. ${ }^{29,30}$ Other factors that have to be considered are the pumping action of water trapped in flexural cracks, ${ }^{30}$ salt build up in the cracks ${ }^{29}$ and reinforcement corrosion. ${ }^{29}$ Impact testing on concrete armour units has indicated that the addition of steel fibrés to the mix increases the stabilizing stress, perhaps as a result of a softer impact surface; however, the effect of fibres was less pronounced in bulky armour units, when compared to slender elements such as beams. $^{31}$

\section{SPECIFICATIONS}

\section{Concrete Mix}

The main concern for marine concrete is permeability, which is determined by the water/cement ratio. Various codes and standards allow a range of permissible water/cement ratios. ${ }^{11}$ It may be reasonable to allow a maximum water/cement ratio of 0.4 for the splash or tidal zones and relax this to 0.45 for the atmospheric and submerged zones. ${ }^{25}$ These low water/cement ratios will also ensure the achievement of high strength, which may also be important, especially if the concrete is not reinforced.

Another way of ensuring a sufficiently low water/cement ratio is to specify a minimum cement content. ${ }^{11}$ The most recent FIP recommendations ${ }^{25}$ suggest 400 $\mathrm{kg} / \mathrm{m}^{3}$ for concrete in the splash zone and $320 \mathrm{~kg} / \mathrm{m}^{3}$ or $360 \mathrm{~kg} / \mathrm{m}^{3}$ elsewhere, depending on whether the maximum aggregate size is $40 \mathrm{~mm}$ or $20 \mathrm{~mm}$. They also suggest that cement contents in excess of $500 \mathrm{~kg} / \mathrm{m}^{3}$ may give rise to drying shrinkage cracking in thin sections or thermal stresses in thick sections.

One way of increasing the binder content, without the ill effects of shrinkage and heat of hydration, is to use a cement replacement agent, such as pfa or rice husk ash. ${ }^{1}$ Typical values for a mix may be $330 \mathrm{~kg} / \mathrm{m}^{3}$ OPC plus $130 \mathrm{~kg} / \mathrm{m}^{3}$ pfa. ${ }^{32}$ As stated before the addition of such pozzolanic material can be beneficial, because it reacts with the $\mathrm{Ca}(\mathrm{OH})_{2}$ component. In addition, the ability to use more fine material in the mix may improve the workability properties. ${ }^{10}$ In general, blended cements, such as the pozzolan mixes above or blastfurnace slag cements, have better resistance to sea water than ordinary portland cement. 
Although American practice requires that the $\mathrm{C}_{3} \mathrm{~A}$ content of OPC be greater than $4 \%$ (to ensure some chloride binding) and less than $10 \%$ (to prevent sulphate attack), laboratory studies have shown that it is only a matter of time before $\mathrm{Cl}^{-}$ions reach the reinforcement ${ }^{15}$ and that the level of $\mathrm{C}_{3} \mathrm{~A}$ in OPC has little bearing on its performance in sea water. 6

A poorly graded aggregate may also contribute towards lack of watertightness. ${ }^{i}$ It is better, therefore, to use mixes based on well graded aggregate as opposed to gap graded ones. A limitation on the maximum aggregate size to be used may also be desirable, although no guidance is given in American or FIP codes. ${ }^{12}$ There is also evidence to indicate that mixes with a greater number of fines produce stronger concretes. ${ }^{33}$

In order to achieve good workability, a sufficient amount of fine particles - i.e. those under 150 and 75 microns - should be present in the mix $^{10}$. Another technique is of course to use water-reducing admixtures, but care should be taken about ensuring the durability of such concretes. ${ }^{34}$

If freeze-thaw conditions are expected, 4 to $7 \%$ of air (by volume) should be entrained. ${ }^{25}$

Given that marine exposure is particularly conducive to corrosion, one way of reinforcing precast concrete armour units is to use polypropylene fibres in the mix. It has been shown that volume percentages over $1 \%$ are not economical, ${ }^{35}$ and a typical value is $0.6 \%$ by volume of $75 \mathrm{~mm}$ fibres. ${ }^{36}$ There seems to be a tendency in more recent times however, to move away from fibre reinforcement to conventional steel reinforcement, which may be able to restrict the spread of local damage better and allow repair more easily. ${ }^{37}$

\section{Other Factors}

If the concrete is reinforced or prestressed, the provision of sufficient cover is of great importance. Here too, there is a range of values permitted by various codes and standards, ${ }^{11}$ e.g. 40 to $75 \mathrm{~mm}$ for reinforced concrete and 45 to $100 \mathrm{~mm}$ for prestressed concrete, depending on the exposure zone. Curing also should be carried out properly, in order to ensure a cover zone of high quality, especially if reinforced or prestressed concrete is being used.

Since the water/cement ratio employed in these mixes will be low, the greatest care must be taken in compacting the concrete, which may be of stiff consistency. Consideration should be given to improving the workability of the mix, as described 
earlier. The proper formation of joints, if any, is crucial for obtaining low permeability concrete.

The restriction of crack width is also very important in reinforced concrete structures. Static cracks and dynamic cracks may be different in nature. ${ }^{11}$

Concrete units or structures should be designed for all stresses experienced in service ás well as transport. Dynamic loading will be especially significant and similarity methods of testing may need to be performed. ${ }^{29,31}$ Transport stresses will be particularly important for unreinforced precast concrete units, such as armour units.

\section{Acknowledgements}

I thank the Natural Resources, Energy and Science Authority (RG/89/E/2) for research support.

\section{References}

1. Mehta P.K. (1982). Durability of concrete in marine environment - A review. SP 65 - Performance of Concrete in Marine Environment. American Concrete Institute, Detroit.

2. Fookes P.G., Simm J.D. \& Barr J.M. (1986). Marine concrete performance in different climatic environments. Marine Concrete - Papers for the International Conference on Concrete in the Marine Environment, pp. 115-130. Concrete Society, London.

3. Gaithwaite John. (1981). The marine environment and structural design. Van Nostrand Reinhold, New York.

4. Conjeaud M.L. (1982). Mechanism of sea water attack on cement mortars. SP 65 Perfomance of Concrete in Marine Environment. American Concrete Institute, Detroit.

5. Buenfeld N.R. \& Newman J.B. (1986). Permeability of marine concrete. Marine Concrete - Papers for the International Conference on Concrete in the Marine Environment, pp. 165-176. Concrete Society, London.

6. Gjorv O.E. (1971). Long-time durability of concrete in seawater. Joumal of the American Concrete Institute, 68(1): 60-67.

7. Smolczyk H.G. (1966). Some observations and new aspects concerning sea-water action on concrete in the tidal zone. RILEM Bulletin 32: 299-304. 
8. Ftikos Ch. \& Parissakis G. (1987). A study on the effect of some ions contained in sea water on hydrated cement compounds. SP 100 - Concrete Durability. Katharine and Bryant Mather International Conference. pp. 1651 - 1665. American Concrete Institute, Detroit.

9. Gjorv O.E. (1989). Steel corrosion in concrete structures - an overview. Gerwick Symposium on International Experience with Durability of Concrete in Marine Environment, pp. 77-89. University of California, Berkeley.

10. Neville A.M. (1981). Properties of concrete, ( $3^{\text {rd }}$ ed.) Pitman, London.

11. Burdall A.C. \& Sharp J.V. (1986). Some aspects of the revision to the U.K. guidance notes for offshore structures. Marine Concrete-Papers for the International Conference on Concrete in the Marine Environment, pp. 37-48. Concrete Society, London.

12. Mehta P.K. (1989). Durability of concrete in marine environment - an overview. Gerwick Symposium on International Experience with Durability of Concrete in Marine Environment, pp. 20-27. University of California, Berkeley.

13. Idorn G.M. (1989). Marine concrete technology - viewed with Danish eyes. Gerwick Symposium on Intemational Experience with Durability of Concrete in Marine Environment, pp. 28-48. University of California, Berkeley.

14. Parker D.G. (1985). Microsilica concrete. Part 1: The material. pp. 21-22. Concrete Society Current Practice Sheet No. 104.

15. Gjorv O.E. \& Vennesland O. (1979). Diffusion of chloride ions from sea water into concrete. Cement and Concrete Research 9(2):229-238.

16. Buenfeld N.R. \& Newman J.B. (1984). The permeability of concrete in a marine environment. Magazine of Concrete Research 36:67-80.

17. Kruger D. \& Penhall D. (1990). Polymers in concrete: a protective measure. Proceedings of the International Conference on Protection of Concrete, pp.653-664. E. \& F.N. Spon, London.

18. Shindou T. \& Naitou T. (1986). Study on durability of polymer-impregnated concrete in the marine environment. Marine Concrete-International Conference on Concrete in the Marine Environment, pp. 293-298. Concrete Society, London.

19. Fukute T. \& Hamada H. (1990). Surface coatings for improving performance of concrete under marine environments. Proceedings of the Intemational Conference on Protection of Concrete, pp. 317-330. E. \& F.N. Spon, London. 
20. McLeod K. \& Woodman N. (1990). Fusion bonded epoxy powder coating for the protection of reinforcing steel. Proceedings of the Intemational Conference on Protection of Concrete, pp. 257-268. E. \& F.N. Spon, London.

21. Figg John (1989). Salt, sulphate and other chemical effects. Gerwick Symposilum on International Experience on Durability of Concrete in Marine Environment, pp. 49-69. University of California, Berkeley.

22. Osborne G.J. (1986). Concrete durability studies at the Building Research Establishment marine exposure site, Shoeburyness. Marine Concrete-International Conference on Concrete in the Marine Environment, pp. 157-164. Concrete Socicty, London.

23. Nishibayashi S., Yamura K. \& Inoue S. (1982). Durability of concrete in sea water: methods of accelerated testing and evaluation. SP 65 - Perfomance of Concrete in Marine Environment. Amcrican Concrete Institute, Detroit.

24. Kasai Y. \& Nakamura N. (1982). Accelerated test methods for durability of cement mortars in sea water. SP65 - Performance of Concrete in Marine Environment. American Concrete Institute, Detroit.

25. Federation Internationale de la Precontrainte (1985). Recommendations for the Design and Construction of Concrete Sea Structures. 29 pp.

26. Malhotra V.M. (1989). Laboratory and field evaluation of freezing and thawing tests. Gerwick Symposium on International Experience on Durability of Concrete in Marine Environment, pp. 213-234. University of California, Berkeley.

27. Popovics S., Simeonov Y., Bozhinov G. \& Barovsky N. (1983). Durability of reinforced concrete in sea water. Ch. 2 in Corrosion of reinforcement in concrete construction, (Ed. A.P. Crane) pp. 19-38. Ellis Horwood, Chichester.

28. Wilkins N.J.M. \& Lawrence P.F. (1983). The corrosion of steel reinforcements in concrete immersed in sea water. Ch. 8 in Corrosion of reinforcement in concrete construction, (Ed. A.P. Crane). pp. 119-141. Ellis Horwood, Chichester.

29. Booth E.D., Leeming M.B., Paterson W.S. \& Hodgkiess T. (1986). Fatigue of reinforced concrete in marine conditions. Marine Concrete - International Conference on Concrete in the Marine Environment, pp. 187-198. Concrete Society, London.

30. Muguruma H. (1989). Low-cycle fatigue behaviour of plain concrete and concrete members under submerged conditions. Gerwick Symposium on International. Experience on Durability of Concrete in Marine Environment, pp. 187-212. University of California, Berkeley. 
31. Burcharth H.F. (1981). Full-scale dynamic testing of Dolosse to destruction. Coastal Engineering 4:229-251.

32. "Winning back Wirral's beaches". Concrete, May 1985. pp. 27-28.

33. Dias W.P.S. (1991). Mix design considerations for unreinforced concrete armour units in a tropical developing country. $3^{\text {rd }}$ International Conference on Coastal and Port Engineering in Developing Countries, Mombasa. pp. 638-648.

34. Dhir R.K. \& Yap A.W.F. (1984). Super-plasticized flowing concrete: Durability properties. Magazine of Concrete Research 36:99-111.

35. Franco L., Materazzi A.L., Noli A. \& Radogna E.F. Impact response of fiber-reinforced concrete elements in the marine environment. AIOM Congress, Naples.

36. "Impact on the environment". Breakwater at Bangor harbour. Concrete, June 1984; pp. 23.

37. Millard S.G., Davies C.D. \& Bungey, J.H. (1990). Behaviour of steel reinforced concrete armour units used in coastal defences. Coastal Engineering 14:57-81. 